DIVISION OF THE HUMANITIES AND SOCIAL SCIENCES

CALIFORNIA INSTITUTE OF TECHNOLOGY

PASADENA, CALIFORNIA 91125

IS THERE A GENDER GAP IN FISCAL POLITICAL PREFERENCES?

R. Michael Alvarez

Edward J. McCaffery

University of Southern California and California Institute of Technology

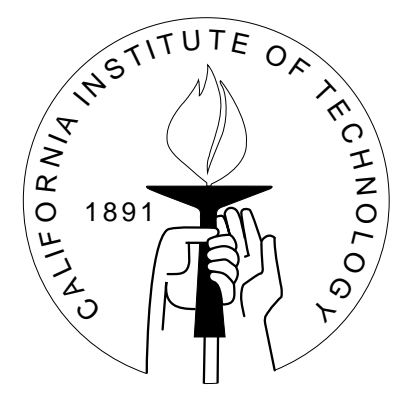

SOCIAL SCIENCE WORKING PAPER 1101 


\title{
Is there a Gender Gap in Fiscal Political Preferences?
}

\author{
R. Michael Alvarez \\ Edward J. McCaffery
}

\begin{abstract}
This paper examines the relationship between attitudes on potential uses of the budget surplus and gender. Survey results show relatively weak support overall for using a projected surplus to reduce taxes, with respondents much likelier to prefer increased social spending on education or social security. There is a significant gender gap with men being far more likely than women to support tax cuts or paying down the national debt. Given a menu of particular types of tax cuts, women are marginally more likely to favor childcare relief or working poor tax credits whereas men are marginally more likely to favor capital gains reduction or tax rate cuts. When primed that the tax laws are biased against two-worker families, men significantly change their preferences, moving from support for general tax rate cuts to support for working poor tax relief, but not to child-care relief. One of the strongest results to emerge is that women are far more likely than men not to express an opinion or to confess ignorance about fiscal matters. Both genders increase their "no opinion" answer in the face of priming, but men more so than women. Further research will explore this no opinion/uncertainty aspect.
\end{abstract}

*We thank the University of Southern California Center for Law, Communications, and Public Policy for a research grant that made our survey research possible. Alvarez thanks the IBM Corporation for supporting his research through the University Matching Grants Program. This paper was presented at the 2000 Annual Meetings of the American Political Science Association. 


\section{Introduction}

Money matters in American politics. In the early days of the American republic, issues such as whether to develop a national central bank and how to deal with the financing of the Revolutionary War were critical and divisive concerns (Aldrich and Grant 1993; Hoadley 1986; Hofstadter 1969). More recently, since the late 1970's fiscal issues such as tax reform and the budget deficit have played a major role in American politics, as by fueling the so-called Reagan Revolution. A new fiscal issue has now appeared on the national scene: the hitherto unthinkable question of how to spend a budget surplus. The combination of budget cuts and tax increases in the early 1990's with unprecedented prosperity in the United States has given fiscal politics a different dynamic. The most salient publicly discussed candidates for this welcome problem have been tax-cutting, deficit reduction, protecting the social security system, and increased general social spending.

There has been little research on the differential appeal of various fiscal policies across interest groups or demographic categories, or on the role such issues have played in determining national electoral outcomes, at least apart from the watershed 1980 presidential campaign. Lacy (1998) studied the impact of the Reagan 1980 tax-cutting platform. Alvarez and Nagler $(1995,1998)$ examined the role of the budget deficit in the 1992 presidential election and the Bob Dole tax cut pledge in the 1996 presidential election, respectively. Such research has been more common on

the state and local level, with Citrin (1979), Cournat et al.(1980) and Sears and Citrin (1985) having all documented the tax revolt that swept through many states following passage of Proposition 13 in California in 1978. Each of these studies has shown that tax-cutting preferences had very important effects on statewide politics in the 1970s and 1980s.

Given the paucity of more general analysis about fiscal political preferences and their impact on electoral results, it is not surprising that there is little by way of more particular analysis of variation in such preferences across demographically distinct subpopulations. Yet fiscal policies have significantly varying effects on different groups. There are for example generational differences in opinions about taxation to go along with the obvious generational implications of fiscal policy (MacManus 1995). There are also gender — or familial structure - biases in tax policy, 
with two-earner households paying sizeable marriage penalties under both the income tax and social security contribution systems, while one-earner households receive large bonuses under each (McCaffery 1997, 1999). Might there be a gender gap in fiscal political preferences? If not, given the shape of the actual law, why not?

Our research agenda (Alvarez and McCaffery 2000) aims to explore these questions. We intend to study the interactions among gender-based differences in fiscal political preferences, the conduct of political campaigns and media coverage thereof, electoral outcomes, and the substantive evolution of the law. Our working hypothesis is that politicians, responding to a perceived difference in political priorities as between men and women, target anti-tax messages to men and pro-spending messages to women. The result is that the substantive law evolves in such a way that tax cuts are more likely to benefit men or one-earner households, leaving women and twoearner households to pay a disproportionate share of government spending programs.

Budget politics provide a fertile testing ground for aspects of our broader hypothesis. The particular analysis of this paper looks at attitudes towards use of the projected budget surplus during a time - the Fall of 1999 - when the surplus was salient but national electoral politics were not; in part, we intend to establish a baseline for later analysis of the effect vel non of presidential politics on fiscal political preferences. Our working hypotheses in this study were that we would find: (1) a gender gap in fiscal political preferences, with men relatively more preferring tax reduction and women increased social spending or "investment" programs; (2) given a menu of various possible tax-cutting proposals, men would favor general tax reduction while women would favor relief targeted to two-worker families or the working poor; and (3) a "priming" experiment, designed to make the gender and familial structure biases in tax salient, would exacerbate the predicted gender gap.

In the remainder of this paper we explore the relationship between gender and the new fiscal politics in America. First we discuss our theoretical framework and our basic operative hypothesis. Second we turn to a discussion of our our unique survey data collection and then present simple tests of our primary hypotheses. Third we present multivariate statistical analyses that also test our hypotheses. We then conclude with a discussion of our results and how they fit into 
a larger research agenda exploring the relationship between gender and fiscal politics in America.

\section{Gender, Fiscal Policy, and American Politics}

As we argued above, fiscal politics have long had a prominent place in American politics. But it is only recently that academic researchers have examined the ways in which gender has shaped the implementation of fiscal policies, with much attention played to welfare and social policy (Gordon 1994; Mink 1995; Orloff 1991; Skocpol 1995) and taxation (McCaffery 1997, 1999). The general finding of this growing literature is that fiscal policies in America have been shaped by gender, with specific policies clearly tailored for men and others tailored for women.

But why are there such clear gender differences in public policy? Here we draw upon three different strains of previous research: public opinion and political behavior, candidates and their campaign strategies, and public policy formation. By putting these three literatures together, we develop our theoretical foundation for our research agenda.

Beginning with public opinion and political behavior, there have been numerous studies documenting gender differences in opinion and behavior. Probably the clearest and most politically influential gender difference has been the well-studied "gender gap" in presidential election voting, in which women have supported Democratic presidential candidates more strongly than men since the 1980 presidential election (Chaney et al. 1998; Mattei and Mattei 1998). More directly to the point of our research, however, is the line of studies documenting differences between men and women in their opinions about social and fiscal policy issues (Gilligan 1982; Kornhauser 1987; Welch and Hibbing 1992). These studies generally agree that women are more generally in favor of redistributive social and fiscal policies than men, as women are more "compassionate" than men (Gilligan 1982) or less driven by immediate "pocketbook" concerns than men (Chaney et al. 1998; Welch and Hibbing 1992).

That gender structures public opinion and voter behavior does not go unnoticed by candidates running for office. In fact, the types of differences which have been observed between men and women's opinions about fiscal and social issues are also mirrored in the observed differ- 
ences between men and women when they run for elected office. Some studies have shown that male candidates focus their campaign rhetoric on "men's issues" like taxes and the federal budget while female candidates focus on "women's issues" like education and health care (Kahn 1993; Fox 1997); other studies have found that gender differences in candidate strategies and rhetoric exist, but in oftentimes carefully nuanced forms (Bystrom 1995; Chaney 1998). Relatedly, one of the common explanations for the gender gap in presidential election voting is that since 1980 the national Democratic party has developed an image as the party better suited to dealing with "women's issues", producing a gender gap in partisanship more than in voting behavior (Cook and Wilcox 1995).

Thus, men and women have different opinions about issues and policy, and they cast their ballots accordingly. Strategic candidates, aware of these differences, craft their campaign messages to appeal to men or women based on their electoral needs. Working simultaneously, this can produce a feedback loop in which gender differences in public opinion and behavior can be sustained and perhaps even enhanced by the actions of strategic candidates targeting their messages to men or women (Alvarez and McCaffery 2000). Thus, we have strong reasons to expect that men and women will have different opinions about social and fiscal issues, which in our research should be apparent in opinions about the potential uses of the current federal budget surplus.

But there is a third level to our theoretical framework, because these candidates, once elected to office, work to carry out their campaign promises. This results in the very gender-based public policy we discussed earlier, where for example some social programs are targeted at single mothers (Gordon 1994; Mink 1995; Orloff 1991; Skocpol 1995) or where tax policy is stacked against women (McCaffery 1997, 1999). Fortunately, Schneider and Ingram (1997) provide an excellent theoretical model of how public policy is targeted towards certain demographic groups. This theoretical model is based on the relative political power of demographic groups and on their socially constructed public perceptions. So in the Schneider and Ingram framework, groups that have strong political power and are positively perceived are "advantaged" in policy development and implementation, while groups that have are weak in power but positively perceived are "dependent"; groups that are negatively perceived but powerful are said to be "contenders", and 
negatively perceived but weak groups are "deviants."

What is especially useful about the Schneider and Ingram framework, though, is the emphasis on the social construction of public perceptions of groups. As Josephson (2000) has noted, this fits neatly with the idea of "framing" widely used in social science, and that these Schneider and Ingram frames are widely used in American politics to discuss social and fiscal policy. Policy makers make a political calculation about populations which are targeted by a public policy, and if policy makers or politicians wish to cut a program they are "framed" in a "deviant" way. For example, "in times of austerity, when social programs are being cut, target populations are constructed as deviant by policymakers through a use of their perceived compliance with appropriate gender-, race-, and class-based social roles, irrespective of empirical evidence regarding the characteristics of target populations" (Josephson 2000, 156).

Thus, while there might be gender-based differences in opinions about fiscal policy, the framing of a fiscal policy proposal can impact policy opinions in the mass public. If presented with a menu of proposals for the use of the current federal budget surplus, but with a frame shaded against female-oriented uses of the surplus, we would expect opinions to be shifted away from these female-oriented uses of the surplus. Conversely, frames which are present female-oriented uses of the surplus in a positive light should shift opinion towards female-oriented uses of the budget surplus.

In conclusion, our theoretical framework builds upon three different strands of the existing literature on gender and politics. We argue that this framework allows us to better understand the relationship between gender and fiscal politics in the brave new world of a federal budget surplus. We expect there to be significant gender-based differences in opinions about the potential uses of the budget surplus, and we also expect that the frames used by politicians and policy makers will influence opinion about the uses of the budget surplus. In the next section of this paper we discuss the data we have collected to examine gender and the new fiscal politics in America and our empirical analysis. 


\section{Survey Method and Empirical Tests}

We tested our basic hypotheses in several ways using original survey data. We used a professional market and survey research firm, Interviewing Services of America, Inc., that conducts weekly national probability samples of American adults. ${ }^{1}$ In four weekly samples of 1,000 respondents each, we posed questions about use of the budget surplus and tax cuts.

The surveys were conducted in the Fall of 1999, a time when the budget surplus was salient but national electoral politics were not. ${ }^{2}$ This timing was intended to gauge public opinion about the use of the budget surplus before the possible impacts of the 2000 presidential election campaign.

In our initial survey week, 1,000 respondents were first given the statement, "As you may know, the federal government is projecting a large budget surplus." Respondents were then asked a series of nonexclusive agree/disagree questions: "Do you agree or disagree with the use of the budget surplus to:"

- reduce taxes

- pay down the national debt

- increase spending on education

- shore up the social security trust fund

Each question also gave respondents the opportunity to state that they did not have an opinion. ${ }^{3}$

In all four survey weeks, all respondents were asked a fixed-choice question about particular types of tax cuts. For one-half of the total pool - 2,000 respondents - this question was preceded by the statement: "Many experts believe that the tax system, because of its marriage penalties and limited child-care relief, is biased against working mothers." (This statement is a fair one sentence summary of McCaffery $(1997,1999)$.) The other 2,000 respondents did not receive this "prime." All 4,000 respondents were then asked: "Of the following tax cuts, which one do you support the most?:" 
- capital gains reduction

- across the board tax rate cut

- child-care relief, or

- more tax credits for the working poor

Respondents were again given the opportunity to say that they had no opinion. ${ }^{4}$

An appendix presents a detailed breakdown of the demographic and political attributes of the four samples, which were consistent with typical telephone samples. ${ }^{5}$ The incidence rate for the telephone surveys was uniformly about $80 \%{ }^{6}$ We are confident in the quality of our data and the validity of our inferences.

\section{Results}

\subsection{General Attitudes}

Table 1 presents the distributions of responses to the four agree-disagree questions about the use of the budget surplus. There is a clear pattern to the rank ordering: the most favored use is to increase education spending (61.6\%), followed by shoring up social security $(51.9 \%)$, paying down the national debt $(42.7 \%)$ and, last, reducing taxes $(38.9 \%)$. These findings are consistent with contemporaneous, generally reported polling data showing that Americans, content with the overall economy, were willing to consider increased social spending and were not clamoring for tax reductions. ${ }^{7}$

\section{Table 1 Goes Here}

The most surprising feature of the budget surplus question was the high nonresponse rates for each question. No opinion responses ranged from $24.6 \%$, for education spending, to $43.9 \%$ the most common answer - for reducing taxes. This suggests that public opinion on the use of a 
budget surplus was not well formed in the Fall of 1999, a fact we later take into account in this paper and also note for our further research.

Table 2 presents the response distributions for the fixed-choice question, sorted by primed or unprimed respondent pools. In the unprimed condition, the rank ordering was for a general tax rate cut $(26.1 \%)$, working poor tax credit $(23.1 \%)$, child-care relief $(16.6 \%)$, and, last, capital gains reductions $(9.4 \%)$. This is consistent with other research showing a general preference for across the board as opposed to targeted tax cuts (Alvarez and McCaffery 2000). As with the agreedisagree questions, a striking result was the high percentage of non-specific responses. Aggregating the various non-specific answers, $25 \%$ of respondents chose none of the particular answers, a response rate second only to that for a general rate reduction.

\section{Table 2 Goes Here}

The lower panel of Table 2 contains results from the primed respondents. There was a change in the rank ordering of preferences for particular tax cuts, with working poor tax credits (24.4\%) replacing general tax rate cut $(21.1 \%)$ as the most preferred, again followed by child-care relief $(15.8 \%)$ and capital gains reduction $(8.6 \%)$. The $\chi^{2}$ test statistic for the differences between the primed and unprimed conditions is 22.3, with 4 degrees of freedom, which is significant at the $p=.00$ level. This is interesting, given that the prime drew attention to the problems of "working mothers," including in particular noting the "limited child-care relief" of existing law. The decline in support for general rate reduction and the increase in support for working poor tax credits, but not child-care relief, suggests that the prime had the effect of making respondents think more of general redistribution to the poor: that the "problem" of working mothers triggers an economic, not a familial demographic, response. The most striking effect of the prime, however, was the increase in the non-specific response rate, which increases to $30.2 \%(n=603$, aggregated across the categories). This becomes by far the leading response, suggesting that attitudes towards particular forms of tax cuts, not well formed in any event, are easily unmoored. 


\subsection{Gender Effects}

Table 3 sorts the agree-disagree questions by gender. In each case, $\chi^{2}$ statistics show that the differences in the distributions between the genders are statistically significant. Women are much less likely than men to support the use of the budget surplus for tax reduction or paying down the national debt, though they are almost equally likely not to disagree with these uses. Women are more likely to support using the surplus for increased education spending, and far less likely to disagree with this possible use. On shoring up social security, women are somewhat less likely to support the use, but also far less likely to disagree with it. On all questions, women are far more likely to express no opinion; indeed, a majority of women respondents expressed no opinion on using the surplus to reduce taxes, and this was the most common answer for paying down the national debt as well. In contrast, men were always more likely to support a given use of the surplus than to express a "don't know" opinion.

\section{Table 3 Goes Here}

Table 4 presents the fixed-choice question, sorted by priming condition and gender. In a simple, preliminary look, men appear to be far more influenced by the priming experiment than women. The priming experiment decreases by almost 7\% (in absolute terms) the proportion of men supporting a general tax rate reduction, $(29 \%$ in the unprimed condition to $22 \%$ in the primed condition). Men in the primed experiment also marginally provide more support for working poor tax credits (increasing by about $4 \%$ ). Most notably, the non-response or no opinion category increases for men by roughly $7 \%$ in the primed condition. Men seem to respond to the priming experiment by being more supportive of working poor tax credits, as well as becoming more uncertain or ambivalent about the use of the budget surplus in general. The differences we observe for men between the primed and unprimed conditions are statistically significant $\left(\chi^{2}=19.9\right.$, four degrees of freedom, $p=.00)$.

\section{Table 4 Goes Here}


Women, on the other hand, differ only very slightly between the unprimed and primed conditions. The only real difference between the two experiments is that there is an almost $5 \%$ increase in the percentage of women who have no opinion or give no response in the primed condition. Statistically speaking, the differences between women in the primed and unprimed conditions are weak, with the $\chi^{2}$ test for differences in the two response distributions significant at the $p=.17$ level ( $\chi^{2}=6.4$, with four degrees of freedom).

Our findings fit interestingly with long-standing research suggesting that men are more narrowly self-interested, or concerned with "pocketbook" issues, while women are more altruistic or sociotropic in their political preferences (Chaney et al. 1998; Welch and Hibbing 1992). Our survey results confirm this prior finding both in the initial agree/disagree question (Table 3) and in the unprimed condition of the fixed choice question (Table 4). In virtually all cases (with shoring up social security posing a slight exception), men are far more likely to prefer choices that minimize "private bads," or general taxes, and women more likely to choose increasing "public goods," spending programs or targeted tax relief. The effect of the prime, however, complicates this analysis. The significant change in men's opinions post prime suggests both that men can respond to priming by becoming more altruistic or sociotropic, and that they view the particular problem of two-worker families as an economic class-based, not a family-based, one (hence the shift towards working poor, not child-care, tax relief). Women's failure to change significantly as a result of the prime suggests that they might have already incorporated sociotropic leanings into their unprimed preferences. This is consistent with prior analysis suggesting that a gender gap in observed fiscal political preferences is highly context dependent, turning on the trade-offs implied by a question (Alvarez and McCaffery 2000), and on more general research suggesting that framing effects loom large in normative evaluations of tax systems (McCaffery and Baron 2000).

\subsection{Multivariate Analysis}

The limitation of our simple analyses in the previous section is that they cannot tell us much about whether the differences between men and women are due to gender and not other factors. This section presents the results of multivariate statistical models that allow us to look precisely at the 
role of gender, controlling for other demographic factors and political beliefs.

We have a wide variety of demographic measures on each respondent: gender, age, whether they have children, educational attainment, income, marital status, racial identification and partisan affiliation. These various measures gave us a wide set of statistical controls to develop a more precise understanding of the relationship between gender and fiscal political preferences.

Many of the explanatory variables were coded as simple binary variables: gender, whether the respondent has children, whether the respondent is single or divorced, whether they are AfricanAmerican, and whether they are Democratic or Republican. Our measures for age, educational attainment, and income were ordinal, with age measured with eleven categories (18-20, 21-24, 25-29, 30-34, 35-39, 40-44, 45-49, 50-54, 55-59, 60-64, and over 65), educational attainment measured with seven categories (some grade school, completed grade school, some high school, completed high school, some college, and some graduate school or more), and income categorized as well with seven levels (under $\$ 20,000, \$ 20,000$ through $\$ 29,999, \$ 30,000$ through $\$ 39,999, \$ 40,000$ through $\$ 49,999, \$ 50,000$ through $\$ 74,999, \$ 75,000$ through $\$ 99,999$, and over $\$ 100,000)$.

We used two types of multivariate models. For the first use of budget surplus questions, which had three discrete choices (agree/disagree/don't know), we employed four different multinomial logit models to examine the effect of each explanatory variable on the relative odds of a respondent agreeing, disagreeing, or not having an opinion.

For the fixed-choice, particular form of tax cut question, lumping together the non-specific responses gave us a five-category discrete variable. We again used multinomial logit to determine the impact of each explanatory variable on the relative odds of picking one of these choices. ${ }^{8}$ The actual multinomial logit results are themselves not simple to understand, as they employ nonlinear statistical models. That is, the coefficient estimates of a multinomial logit analysis are expressions of the estimated impact of a particular independent variable on the probability of some choice being made, depending on the values of all of the other independent variables. This dependence of one variable's estimate on the values of other variables makes easy understanding of multinomial logit results complicated. Rather than discussing the actual multinomial logit re- 
sults, we instead concentrate our presentation on the estimated probability effects derived from the multinomial logit models. ${ }^{9}$

We begin with the four agree/disagree questions. The estimated effects for "reduce taxes" and "pay down the national debt" questions are in the top two panes of Table 5; those for "increased education spending" and "shore up social security" questions are in the bottom two panels of Table 5. In each panel of the table, we provide estimated effects for each of the independent variables on the probability that a hypothetical average respondent would agree, disagree, or express no opinion for each policy question. The estimates which are starred represent ones which are statistically different from zero at the $p=.05$ level of statistical significance ${ }^{10}$

\section{Table 5 Goes Here}

Table 5 shows that women, controlling for all other variables, are about .09 less likely than men to favor either tax or deficit reduction, but are much more likely than men to express no opinion (.14 and .12, respectively). There are also relatively strong effects for education. Increasing educational attainment leads to a much greater probability of disagreeing with tax reduction but agreeing with paying down the national debt. Partisanship also matters. Self-identified Democrats disagree about reducing taxes but agree with paying down the national debt. Republicans, in contrast, favor reducing taxes, but side with Democrats in agreeing to reduce the national debt. Self-identifying as being either a Democrat or a Republican makes one significantly more likely to have an opinion about any of the uses.

The lower panels of Table 5 provides analogous results for education spending and shoring up the social security system. Again gender is significant. Women agree with increased education spending, but seem uncertain or ambivalent about shoring up social security, relative to men. Once again being a woman predicts a greater likelihood of no specific opinion. Age, not a major factor in the tax or debt reduction options, is not surprisingly a strong factor here. Increasing respondent age leads to much less support for education but much more for social security. Increasing educational attainment leads to greatly increased likelihoods of supporting both educa- 
tion and social security protection. Partisanship again matters. Democrats (for) and Republicans (against) disagree over educational spending but roughly agree over shoring up social security. Partisanship also, again not surprisingly, makes it far more likely that a given respondent has an opinion.

Table 6 gives the multinomial logit analysis of the fixed-choice tax cut question, where we employed the priming condition. This model used all of the independent variables in the previous ones, but we added two new variables. One is a binary variable for whether the respondent was "primed" or not. The second is an interaction variable between the respondent's gender and whether she was primed. The survey question had four specific response options (capital gains, tax rate reduction, child-care relief, and tax credits for the working poor), and we lumped together all non-specific responses.

\section{Table 6 Goes Here}

The first three rows of Table 6 contain results that test our primary hypotheses. Controlling for all other variables, gender matters. Women were somewhat less likely than men to choose reducing capital gains or general tax rate relief as their primary choice for the use of the budget surplus. Women were slightly more likely to focus on child-care relief than men, but slightly less likely to pick working poor credits. Once again, women are far more likely than men to have no opinion about the use of the budget surplus.

Next, respondents who were primed were less likely to state that capital gains or tax rate relief were their priorities. Those in the priming condition were more likely to state that working poor credits were their priority, but these same respondents were slightly less likely to state that child-care relief was their priority. The prime also produced a higher no opinion rate than in the non-experimental condition.

Last, the interaction between gender and the prime did not have a strong impact on responses. The only statistically reliable result is that primed women were less likely to choose working poor tax credits relative to men; recall that men reacted to the prime rather dramatically by shifting 
from general rate reduction to working poor relief. None of the other interactions between gender and our priming condition were statistically nor substantively significant.

Other results in Table 6 merit discussion. Age, education, income, race and partisanship all had important effects. Older respondents are much less likely to choose child-care relief. Increased educational attainment led to an increased probability for supporting general tax rate cuts. Higher family income led to a higher probability of support for capital gains reductions and general tax rate cuts, but lower odds of support for child-care or working poor tax credits. Blacks took just the opposite tack - relatively more supporting child-care and working poor tax relief, and opposing general rate or capital gains tax reductions. Democrats were much more likely to favor working poor tax credits while Republicans were much more likely to favor tax rate relief and capital gains tax cuts.

\section{Conclusions}

There is indeed a gender gap in fiscal political preferences, though it is not always easy to discern. This most general finding of our research is consistent with previous work that has assumed or argued that women and men have different political and economic focuses and concerns (Gilligan 1982; Welch and Hibbing 1992). Also, our results are consistent with our theoretical framework which predicted that these gender gaps in fiscal political preferences should exist.

In the Fall of 1999, without a pressing national political campaign and with the new issue of possible uses for a budget surplus to consider, we found an overall low level of salience on fiscal political issues. In this context and consistent with the trend of prior research, we found that men were more likely to support narrowly pocketbook issues, being more likely than women to prefer minimizing "private bads." Women, in contrast, were more altruistic or sociotropic, more likely to support increased spending on public goods (Welch and Hibbing 1992).

This simple story is too simple. Recent studies of the gender gap in presidential elections have underscored the complicated relationship between gender and political behavior, as by showing for example that no one single explanation exists for understanding the gender gap in presidential 
elections since 1980 (Chaney et al. 1998). Our work shows again that the gender gap is fiscal and tax policy issues is not a simple phenomenon - it is complicated and context dependent.

One striking aspect of our survey, for example, was the high level of professed ignorance and/or indifference and, even more striking, the high gender gap in this uncertainty category. Women are far more likely not to have an opinion about fiscal political issues. This is consistent with at least one recent study that uncovered systematic, persistent gender differences in political information and knowledge, with women tending to know less about politics than men, even controlling for many of the variables usually associated with political awareness (Delli Carpini and Keeter 2000). Whether ignorance or indifference in the domain of fiscal and tax issues is due to fundamental uncertainty by women about these specific policy issues (e.g. Alvarez 1998) or whether this arises because of ambivalence (e.g. Alvarez and Brehm 1995) warrants further analysis.

A second striking result of our survey was that men but not women responded to an issues "prime" that drew attention to the biases of the tax system against working mothers. In the face of this prime, men became both more uncertain and more sociotropic, although their particular response indicated an economic concern with redistribution rather than a categorical concern with working mothers. The varying effect of the prime suggested that women had already incorporated their sociotropic leanings into their preferences, whereas men have to - but can be - prodded into this.

The combination of high levels of uncertainty and ignorance with evidence that preferences can be changed by priming devices - and the fact that each of these elements differs between the genders - suggests that trends in fiscal political preferences over time bear close watching. As electoral campaigns approach, do fiscal political matters become more salient, and are the effects parallel between the genders? Do candidates or political parties tailor certain messages for men and others for women, to "prime" them differently? How and when if at all is this strategy successful? There has been little empirical research about the links among informational and opinion-oriented gender gaps and the conduct of political campaigns. Thus, given the high level of public uncertainty and ignorance, the stakes involved, and the potential for divergent opin- 
ions between the genders, fiscal political issues are an interesting testing ground for studying the interactions among gender, politics, and law. 


\title{
Endnotes
}

\begin{abstract}
${ }^{1}$ Interviewing Services of America, Inc., regularly conducts marketing and political surveys; this company has conducted political surveys recently for the Los Angeles Times and for previous research reported by Alvarez and Nagler (2000).

${ }^{2}$ Specifically, the weekly samples were obtained in October 18-22, 1999 (Sample 1), November 1-5, 1999 (Sample 2), November 29-December 3, 1999 (Sample 3), and December 6-10, 1999 (Sample 4). At this time, numerous newspaper accounts were relating the political success of President Clinton's refusal to use the surplus to reduce taxes. See Gallup Poll Releases July 21, 1999, “Americans Favor Increased Medicare Spending Over Tax Cuts"; John M. Broder, “Clinton Eager to Veto Tax Cut," NY Times Abstracts, September 2, 1999 at 22; Eric Pianin and Juliet Eilperin, "Clinton Will Submit Social Security Plan; He Assails GOP as Final Budget Showdown Looms," Washington Post, Oct. 24, 1999 at A1.
\end{abstract}

${ }^{3}$ For example, the reduce taxes question read in full: "Do you agree or disagree with the use of the budget surplus to reduce taxes, or don't you have an opinion?"

\begin{abstract}
${ }^{4}$ Specifically, half of our 4000 respondents received the "primed" question: "Many experts believe that the tax system, because of its marriage penalties and limited child-care relief, is biased against working mothers. Of the following tax cuts, which one do you support the most, capital gains reduction, across the board tax rate cut, child-care relief, more tax credits for the working poor, or don't you have an opinion?" The other half of our total sample received the "unprimed" question, which was worded: "Of the following tax cuts, which one do you support the most, capital gains reduction, across the board tax rate cut, child-care relief, more tax credits for the working poor, or don't you have an opinion?"

${ }^{5}$ In comparison with the most recent National Election Studies sample (1998), our samples are somewhat more male (our samples are almost exactly 50\% male and 50\% female, while the NES is $46 \%$ men and $54 \%$ women) and somewhat less white (the NES is $86 \%$ white, $12 \%$ African American, and only $2 \%$ other non-whites; our samples have between 77 and $80 \%$ white respondents, 9 to $11 \%$ African-American, 5 to $8 \%$ Latino, $2 \%$ Asian, and 4 to $5 \%$ other ethnic or racial background). Our samples have roughly the same educational attainment and income distributions. All of our sample distributions are in the appendix of this paper.
\end{abstract}

${ }^{6}$ Interviewing Services of American, Inc., computes the survey incidence rates as follows. They take the total number of completed interviews (1000) and add to that the number of suspended and broken-off interviews; they divide this by the number of total screening contacts to produce the incidence rate.

${ }^{7}$ For example, the Los Angeles Times conducted a telephone poll in November 13-18, 1999 of 1800 adults nationally, and asked the following question: "As you may know, the Congressional Budget Office says there will be about a one trillion dollar budget surplus over the next ten years. This surplus is in addition to the funds collected for Social Security. Some say we should use the surplus for a small tax cut and use most of the money to strengthen social security and Medicare and increase spending on areas such as education; others want to use most of the surplus for a tax cut. Which of these options comes closer to your view?" $80 \%$ of the respondents were in favor of using the budget surplus for "most programs", $14 \%$ for a "tax cut", and 6\% did not have an opinion.

${ }^{8}$ As there was a fairly high rate of survey item non-response on income, with roughly $30 \%$ of the respondents not providing any information about their income, we used multiple imputation to produce a series of five complete data matrices for our multivariate analysis (Honaker et al. 1999). Simply put, multiple imputation uses information from responses an individual did provide to produce many estimates for the missing responses. Multiple estimates for missing responses are critical as that is the only way in which to incorporate estimation uncertainty easily into the multiple imputation procedure. We then estimates the analysis model (in our case the multinomial logit models) for each of the imputed datasets; then we simply average the results across the datasets and report those averages in this paper. We used the Amelia package in GAUSS for our multiple imputation analysis (Honaker et al. 1999). Additional details and results are available from the authors upon request. We then estimate our multinomial logit models one each of the five complete data matrices, and we report the averaged results across the five estimations. 
${ }^{9}$ We present the actual averaged model estimates in an appendix, in Tables 9 and 10. Interested readers can refer to those tables to examine the actual multinomial logit results.

${ }^{10}$ We produce these probability estimates using the Clarify software package (Tomz et al. 2000). 


\section{Bibliography}

Aldrich, John H. and Ruth W. Grant. 1993. "The Antidederalists, the first Congress and the first national parties." Journal of Politics 55: 295-326.

Alvarez, R. Michael. 1998. Information and Elections. Ann Arbor: The University of Michigan Press.

Alvarez, R. Michael and John Brehm. 1995. “American Ambivalence Towards Abortion Policy: A Heteroskedastic Probit Method for Assessing Conflicting Values." American Journal of Political Science 39: 1055-82.

Alvarez, R. Michael Alvarez and Edward J. McCaffery. 2000. "Gender and Tax" in Sue TollesonRinehart and Jyl J. Josephson, editors, Gender and American Politics: Women, Men and the Political Process (New York: M.E. Sharpe).

Alvarez, R. Michael and Jonathan Nagler, 2000. “The Expressive American Voter." California Institute of Technology, Manuscript.

Alvarez, R. Michael and Jonathan Nagler, 1998. "When Politics and Models Collide: Estimating Models of Multicandidate Elections." American Journal of Political Science 42,1: 55-96.

Alvarez, R. Michael and Jonathan Nagler, 1995. “Voter Choice in 1992: Economics, Issues and Anger." American Journal of Political Science 39,3: 714-744.

Bystrom, Dianne. 1995. Candidate Gender and the Presentation of Self: The Videostyles of Men and Women in U.S. Senate Campaigns. Norman: University of Oklahoma, Ph.D. Dissertation.

Chaney, Carol Kennedy. 1998. Vote Choice in Senate Elections: The Impact of Campaigns and Candidate Gender, 1988-1992. Riverside: University of California, Riverside, Ph. D. Dissertation.

Chaney, Carol Kennedy, R. Michael Alvarez, and Jonathan Nagler. 1998. "Explaining the Gender Gap in U.S. Presidential Elections, 1980-1992." Political Research Quarterly 51(2): 311-40.

Citrin, Jack. 1979. "Do People Want Something for Nothing? Public Opinion on Taxes and Spend- 
ing." National Tax Journal 32, 113-129.

Cook, Elizabeth Adell and Clyde Wilcox. 1995. "Women Voters in the 'Year of the Women'." In Herbert E. Weisberg, ed., Democracy's Feast: Elections in America, pp 195-219. Chatham: Chatham House.

Cournat, P.N., E.M. Gramlich, and D. L. Rubinfeld. 1980. "Why Voters Support Tax Limitation Amendments: The Michigan Case." National Tax Journal 33, 1-20.

Delli Carpini, Michael X. and Scott Keeter. 2000. “Gender and Political Knowledge." In Sue Tolleson-Rinehart and Jyl J. Josephson, editors, Gender and American Politics: Women, Men and the Political Process (New York: M.E. Sharpe).

Fox, Richard Logan. 1997. Gender Dynamics in Congressional Elections. Thousand Oaks: Sage Publications.

Gilligan, Carol. 1982. Understanding the Gender Gap: An Economic History of American Women. Cambridge: Harvard University Press.

Gordon, Linda. 1994. Pitied But Not Entitled: Single Mothers and the History of Welfare. New York: The Free Press.

Hoadley, John F. 1986. Origins of American Political Parties, 1789-1803. Lexington: University of Kentucky Press.

Hofstadter, Richard. 1969. The Idea of a Party System: The Rise of Legitimate Opposition in the United States, 1780-1840. Berkeley: University of California Press.

Honaker, James, Anna Joseph, Gary King, Kim Shreve and Nannibal Singh. 1999. "Amelia: A Program for Missing Data." http://gking.harvard.edu/amelia/amelia.zip

Josephson, Jyl J. 2000. "Gender and Social Policy" in Sue Tolleson-Rinehart and Jyl J. Josephson, editors, Gender and American Politics: Women, Men and the Political Process (New York: M.E. Sharpe).

Kahn, Kim Fridkin. 1996. The Political Consequences of Being a Woman: How Stereotypes Influence the 
Conduct and Consequences of Political Campaigns. New York: Columbia University Press.

Kornhauser, Marjorie E. 1987. “The Rhetoric of the Anti-Progressive Income Tax Movement: A Typical Male Reaction." Michigan Law Review 86: 465-523.

Lacy, Dean. 1998. “Electoral Support for Tax Cuts: A Case Study of the 1980 American Presidential Election." American Politics Quarterly 26,3: 288-307.

MacManus, Susan A. 1995. "Taxing and Spending Policies: A Generational Perspective." Journal of Politics 57, 3:607-629.

Mattei, Laura Winsky and Franco Mattai. 1998. “If Men Stayed Home ... The Gender Gap in Recent Congressional Elections." Political Research Quarterly 51: 411-436.

McCaffery, Edward J. 1997 and 1999(paper). Taxing Women. (Chicago: University of Chicago Press.)

McCaffery, Edward J. and Jon Baron. 2000. "How Perspective and Framing Affect the Evaluation of Tax Policies." work in progress.

Mink, Gwendolyn. 1995. The Wages of Motherhood: Inequality in the Welfare State, 1917-1942. Ithaca: Cornell University Press.

Orloff, Ann Shola. 1991. "Gender in Early U.S. Social Policy." Journal of Policy History 3: 249-281.

Schneider, Anne and Helen Ingram. 1997. Policy Design for Democracy. Lawrence: University Press of Kansas.

Skocpol, Theda. 1995. Protecting Soldiers and Mothers: The Political Origins of Social Policy in the United States. Cambridge: Harvard University Press.

Sears, David O. and Jack Cirin. 1985. Tax Revolt: Something for Nothing in California (Cambridge, Mass: Harvard University Press).

Tomz, Michael, Jason Wittenberg and Gary King. 2000. “Clarify: Software for Interpreting and 
Presenting Statistical Results." http://gking.harvard.edu/files/clarify.zip

Turnier, William J., Pamela Johnston Conover and David Lowery. 1996. “Redistributive Justice and Cultural Feminism." American University Law Review 45: 1275-1322.

Welch, Susan, and John Hibbing. 1992. "Financial Conditions, Gender and Voting in American National Elections." Journal of Politics 54(1):197-213. 
Table 1: Uses of Budget Surplus

\begin{tabular}{l|ccc} 
& Agree & Disagree & Don't Know \\
\hline & \multicolumn{3}{|c}{ To Reduce Taxes } \\
Percent & 38.9 & 17.2 & 43.9 \\
Number & 389 & 172 & 439 \\
\hline & \multicolumn{3}{|c}{ To Pay Down National Debt } \\
Percent & 42.7 & 15.6 & 41.7 \\
Number & 427 & 156 & 417 \\
\hline & \multicolumn{4}{|c}{ To Increase Education Spending } \\
Percent & 61.6 & 13.8 & 24.6 \\
Number & 616 & 138 & 246 \\
\hline & \multicolumn{4}{|c}{ To Shore Up Social Security } \\
Percent & 51.9 & 14 & 34.1 \\
Number & 519 & 140 & 341 \\
\hline
\end{tabular}


Table 2: Support for Tax Cuts

\begin{tabular}{l|cc} 
& Percent & Number \\
\hline \multirow{2}{*}{ Capital Gains Reduction } & \multicolumn{2}{|c}{ Unprimed } \\
Tax Rate Cut & 26.4 & 188 \\
Child Care Relief & 16.6 & 321 \\
Working Poor Tax Credits & 23.1 & 461 \\
Don't Care, No Opinion & 25.0 & 499 \\
& \multicolumn{2}{|c}{ Primed } \\
Capital Gains Reduction & 8.6 & 172 \\
Tax Rate Cut & 21.1 & 421 \\
Child Care Relief & 15.8 & 316 \\
Working Poor Tax Credits & 24.4 & 488 \\
Don't Care, No Opinion & 30.2 & 603 \\
\hline
\end{tabular}

Note: Don't Care, No Opinion category contains an aggregation of nonresponse options: No Preference, No Opinion, Don't Care, or Don't Know. The differences between primed and unprimed conditions are statistically significant, $\chi^{2}=22.3,4$ degrees of freedom, $p=.00$. 
Table 3: Gender and Uses of Budget Surplus

\begin{tabular}{|c|c|c|c|c|c|c|}
\hline & \multicolumn{3}{|c|}{ Men } & \multicolumn{3}{|c|}{ Women } \\
\hline & Agree & Disagree & Don't Know & Agree & Disagree & Don't Know \\
\hline \multirow{4}{*}{$\begin{array}{l}\text { Percent } \\
\text { Number } \\
\chi^{2}\end{array}$} & \multicolumn{6}{|c|}{ To Reduce Taxes } \\
\hline & 44.4 & 19.0 & 36.6 & 33.4 & 15.4 & 51.2 \\
\hline & 222 & 95 & 183 & 167 & 77 & 256 \\
\hline & & & & & & $21.8^{*}$ \\
\hline \multirow{5}{*}{$\begin{array}{l}\text { Percent } \\
\text { Number } \\
\chi^{2}\end{array}$} & \multicolumn{6}{|c|}{ To Pay Down National Debt } \\
\hline & 49.0 & 15.2 & 35.8 & 36.4 & 16.0 & 47.6 \\
\hline & 245 & 76 & 179 & 182 & 80 & 238 \\
\hline & & & & & & $17.7^{*}$ \\
\hline & \multicolumn{6}{|c|}{ To Increase Education Spending } \\
\hline Percent & 59.8 & 17.8 & 22.4 & 63.4 & 9.8 & 26.8 \\
\hline \multirow{3}{*}{$\chi^{2}$} & 299 & 89 & 112 & 317 & 49 & 134 \\
\hline & & & & & & $14.1^{*}$ \\
\hline & \multicolumn{6}{|c|}{ To Shore Up Social Security } \\
\hline Percent & 54.0 & 16.2 & 29.8 & 49.8 & 11.8 & 38.4 \\
\hline Number & 270 & 81 & 149 & 294 & 59 & 192 \\
\hline$\chi^{2}$ & & & & & & $9.7^{*}$ \\
\hline
\end{tabular}


Table 4: Support for Tax Cuts by Gender

\begin{tabular}{l|cc|cc} 
& \multicolumn{3}{|c}{ Men } & \multicolumn{3}{c}{ Women } \\
& Percent & Number & Percent & Number \\
\hline \multirow{3}{*}{ Capital Gains Reduction } & 10.1 & 101 & 7.1 & 71 \\
Tax Rate Cut & 22.8 & 228 & 19.3 & 193 \\
Child Care Relief & 14.0 & 140 & 17.6 & 176 \\
Working Poor Tax Credits & 25.4 & 254 & 23.4 & 234 \\
No Opinion & 27.7 & 277 & 32.6 & 326 \\
\hline \multirow{4}{*}{ Capital Gains Reduction } & 11.9 & 119 & 6.9 & 69 \\
Tax Rate Cut & 29.3 & 294 & 22.8 & 227 \\
Child Care Relief & 15.3 & 153 & 17.9 & 178 \\
Working Poor Tax Credits & 21.7 & 218 & 24.4 & 243 \\
No Opinion & 21.8 & 219 & 28.1 & 280 \\
\hline
\end{tabular}

Note: The differences between the response distributions for men and women in the primed condition, and comparing men and women in the unprimed condition, are both statistically significant (the $\chi^{2}$ for the men-women comparison in the primed condition is 17.1, 4 degrees of freedom, $p=.00$; the $\chi^{2}$ for the men-women comparison in the unprimed condition is 32.6, 4 degrees of freedom, $p=.00$.) The other comparison of distributions, where men are compared between primed and unprimed conditions, and where women are compared between primed and unprimed conditions, are statistically significant for men $\left(\chi^{2}=19.9,4\right.$ degrees of freedom, $\left.p=.00\right)$ but is only significant at the $p=.17$ level for women $\left(\chi^{2}=6.4\right.$, four degrees of freedom.) 
Table 5: Estimated Effects on Independent Uses of Budget Surplus

\begin{tabular}{|c|c|c|c|c|c|c|}
\hline \multirow[b]{2}{*}{ Variable } & \multicolumn{3}{|c|}{$\begin{array}{l}\text { Reduce Taxes } \\
\text { Probability of: }\end{array}$} & \multicolumn{3}{|c|}{$\begin{array}{l}\text { National Debt } \\
\text { Probability of: }\end{array}$} \\
\hline & Agree & Disagree & Don't Know & Agree & Disagree & Don't Know \\
\hline Women & $-0.09^{*}$ & $-0.06^{*}$ & $0.14^{*}$ & $-0.09^{*}$ & -0.02 & $0.12^{*}$ \\
\hline Age & 0.01 & 0.05 & $-0.08^{*}$ & 0.06 & -0.03 & -0.04 \\
\hline Children & $0.07^{*}$ & -0.01 & $-0.07^{*}$ & 0.01 & 0.00 & $0.08^{*}$ \\
\hline Education & $-0.11^{*}$ & $0.17^{*}$ & $-0.09^{*}$ & $0.22^{*}$ & 0.03 & $-0.24^{*}$ \\
\hline Income & 0.06 & $0.08^{*}$ & $-0.12^{*}$ & 0.02 & 0.03 & $-0.05^{*}$ \\
\hline Single & $-0.06^{*}$ & -0.00 & $0.04^{*}$ & 0.01 & -0.01 & 0.00 \\
\hline Formerly married & -0.02 & 0.03 & -0.03 & 0.04 & -0.00 & $-0.04^{*}$ \\
\hline Black & $0.08^{*}$ & $-0.07^{*}$ & -0.02 & $-0.10^{*}$ & 0.05 & $0.05^{*}$ \\
\hline Democrats & -0.00 & $0.13^{*}$ & $-0.12^{*}$ & $0.10^{*}$ & 0.05 & $-0.14^{*}$ \\
\hline \multirow[t]{4}{*}{ Republicans } & $0.16^{*}$ & $0.06^{*}$ & $-0.20^{*}$ & $0.07^{*}$ & $0.09 *$ & $-0.16^{*}$ \\
\hline & \multicolumn{3}{|c|}{ Education } & \multicolumn{3}{|c|}{ Social Security } \\
\hline & \multicolumn{3}{|c|}{ Probability of: } & \multicolumn{3}{|c|}{ Probability of: } \\
\hline & Agree & Disagree & Don't Know & Agree & Disagree & Don't Know \\
\hline Women & $0.05^{*}$ & $-0.06^{*}$ & $0.03^{*}$ & $-0.05^{*}$ & $-0.06^{*}$ & $0.09 *$ \\
\hline Age & $-0.18^{*}$ & 0.06 & $0.09 *$ & $0.15^{*}$ & 0.05 & -0.10 \\
\hline Children & $0.08^{*}$ & 0.03 & $-0.09^{*}$ & 0.01 & $0.07^{*}$ & $-0.08^{*}$ \\
\hline Education & $0.14^{*}$ & 0.05 & $-0.20^{*}$ & $0.15^{*}$ & 0.06 & $-0.20^{*}$ \\
\hline Income & $-0.12^{*}$ & 0.02 & $0.07^{*}$ & 0.02 & 0.04 & $-0.04^{*}$ \\
\hline Single & 0.01 & -0.02 & 0.01 & 0.01 & 0.02 & -0.02 \\
\hline Formerly married & $0.07^{*}$ & 0.00 & $-0.07^{*}$ & 0.00 & $0.08^{*}$ & $-0.08^{*}$ \\
\hline Black & -0.00 & -0.04 & 0.03 & -0.03 & -0.05 & $0.07^{*}$ \\
\hline Democrats & $0.15^{*}$ & 0.00 & $-0.15^{*}$ & $0.16^{*}$ & 0.02 & $-0.17^{*}$ \\
\hline Republicans & -0.02 & $0.09 *$ & $-0.09^{*}$ & $0.09^{*}$ & 0.05 & $-0.13^{*}$ \\
\hline
\end{tabular}

Note: Table entries are estimated probability effects. The starred entries are estimates which are statistically distinct from zero at the $p=.05$ level. 
Table 6: Estimated Effects on Uses of Budget Surplus

\begin{tabular}{l|ccccc} 
& \multicolumn{5}{|c}{ Effects on Probability of Choosing: } \\
Variable & Capital Gains & Tax Rate Relief & Child Care & Working Poor Credits & No Opinion \\
\hline Women & $-0.04^{*}$ & $-0.06^{*}$ & $0.02^{*}$ & -0.01 & $0.08^{*}$ \\
Primed & $-0.02^{*}$ & $-0.07^{*}$ & $-0.02^{*}$ & $0.04^{*}$ & $0.06^{*}$ \\
Interaction & 0.02 & 0.02 & $0.02^{*}$ & $-0.04^{*}$ & $-0.02^{*}$ \\
Age & $0.02^{*}$ & $0.05^{*}$ & $-0.21^{*}$ & $0.05^{*}$ & $0.10^{*}$ \\
Children & $-0.03^{*}$ & 0.01 & $0.04^{*}$ & $0.03^{*}$ & $-0.06^{*}$ \\
Education & $0.04^{*}$ & $0.12^{*}$ & $0.04^{*}$ & 0.01 & $-0.21^{*}$ \\
Income & $0.09^{*}$ & $0.15^{*}$ & $-0.09^{*}$ & $-0.16^{*}$ & 0.00 \\
Single & 0.01 & $-0.06^{*}$ & $-0.02^{*}$ & $-0.02^{*}$ & $0.09^{*}$ \\
Formerly married & -0.01 & $-0.02^{*}$ & $0.02^{*}$ & -0.01 & $0.02^{*}$ \\
Black & $-0.04^{*}$ & $-0.08^{*}$ & $0.04^{*}$ & $0.05^{*}$ & $0.03^{*}$ \\
Democrats & $0.02^{*}$ & -0.00 & $0.05^{*}$ & $0.13^{*}$ & $-0.20^{*}$ \\
Republicans & $0.07^{*}$ & $0.15^{*}$ & $-0.02^{*}$ & $-0.04^{*}$ & $-0.17^{*}$ \\
\hline
\end{tabular}




\section{Appendix}

Table 7: Survey Sample Details

\begin{tabular}{|c|c|c|c|c|}
\hline Attribute & Survey 1 & Survey 2 & Survey 3 & Survey 4 \\
\hline \multicolumn{5}{|l|}{ Gender } \\
\hline Men & $50 \%$ & $50.1 \%$ & $50.2 \%$ & $50.0 \%$ \\
\hline Women & $50 \%$ & $49.9 \%$ & $49.8 \%$ & $50.0 \%$ \\
\hline \multicolumn{5}{|l|}{ Education } \\
\hline Some Grade School & $2.0 \%$ & $1.8 \%$ & $2.1 \%$ & $2.1 \%$ \\
\hline Complete Grade School & $3.3 \%$ & $2.6 \%$ & $2.2 \%$ & $1.5 \%$ \\
\hline Some High School & $8.5 \%$ & $8.7 \%$ & $8.6 \%$ & $8.1 \%$ \\
\hline Compete High School & $29.7 \%$ & $28.8 \%$ & $32.1 \%$ & $31.4 \%$ \\
\hline Some College & $24.0 \%$ & $27.2 \%$ & $24.4 \%$ & $26.4 \%$ \\
\hline Compete College & $21.3 \%$ & $22.3 \%$ & $23.1 \%$ & $22.4 \%$ \\
\hline Some Grad School & $11.3 \%$ & $8.5 \%$ & $7.7 \%$ & $8.2 \%$ \\
\hline \multicolumn{5}{|l|}{ Income } \\
\hline Under $\$ 20 \mathrm{~K}$ & $16.4 \%$ & $20.0 \%$ & $14.8 \%$ & $18.4 \%$ \\
\hline$\$ 20 \mathrm{~K}-\$ 30 \mathrm{~K}$ & $17.8 \%$ & $16.8 \%$ & $20.3 \%$ & $14.5 \%$ \\
\hline$\$ 30 \mathrm{~K}-\$ 40 \mathrm{~K}$ & $17.9 \%$ & $14.4 \%$ & $16.9 \%$ & $14.5 \%$ \\
\hline$\$ 40 \mathrm{~K}-\$ 50 \mathrm{~K}$ & $11.3 \%$ & $13.5 \%$ & $13.1 \%$ & $13.7 \%$ \\
\hline$\$ 50 \mathrm{~K}-\$ 75 \mathrm{~K}$ & $19.1 \%$ & $18.7 \%$ & $17.6 \%$ & $23.2 \%$ \\
\hline$\$ 75 \mathrm{~K}-\$ 100 \mathrm{~K}$ & $10.4 \%$ & $8.2 \%$ & $9.1 \%$ & $6.0 \%$ \\
\hline Over $\$ 100 \mathrm{~K}$ & $7.1 \%$ & $8.5 \%$ & $8.2 \%$ & $9.8 \%$ \\
\hline \multicolumn{5}{|l|}{ Race } \\
\hline White & $76.7 \%$ & $76.6 \%$ & $79.6 \%$ & $77.6 \%$ \\
\hline African American & $8.9 \%$ & $10.9 \%$ & $9.3 \%$ & $10.6 \%$ \\
\hline Latino & $8.1 \%$ & $5.1 \%$ & $5.2 \%$ & $4.8 \%$ \\
\hline Asian & $2.4 \%$ & $2.3 \%$ & $2.3 \%$ & $1.8 \%$ \\
\hline Other & $3.9 \%$ & $5.2 \%$ & $3.6 \%$ & $5.2 \%$ \\
\hline \multicolumn{5}{|l|}{ Partisanship } \\
\hline Democratic & $29.4 \%$ & $28.5 \%$ & $26.0 \%$ & $26.0 \%$ \\
\hline Republican & $22.7 \%$ & $25.3 \%$ & $23.8 \%$ & $23.5 \%$ \\
\hline Independent & $23.3 \%$ & $24.3 \%$ & $24.6 \%$ & $20.6 \%$ \\
\hline Other & $24.6 \%$ & $21.9 \%$ & $25.6 \%$ & $29.9 \%$ \\
\hline \multicolumn{5}{|l|}{ Incidence Rate } \\
\hline & $83.0 \%$ & $83.0 \%$ & $83.6 \%$ & $84.0 \%$ \\
\hline
\end{tabular}


Table 8: Breakdowns of Priming Experiment

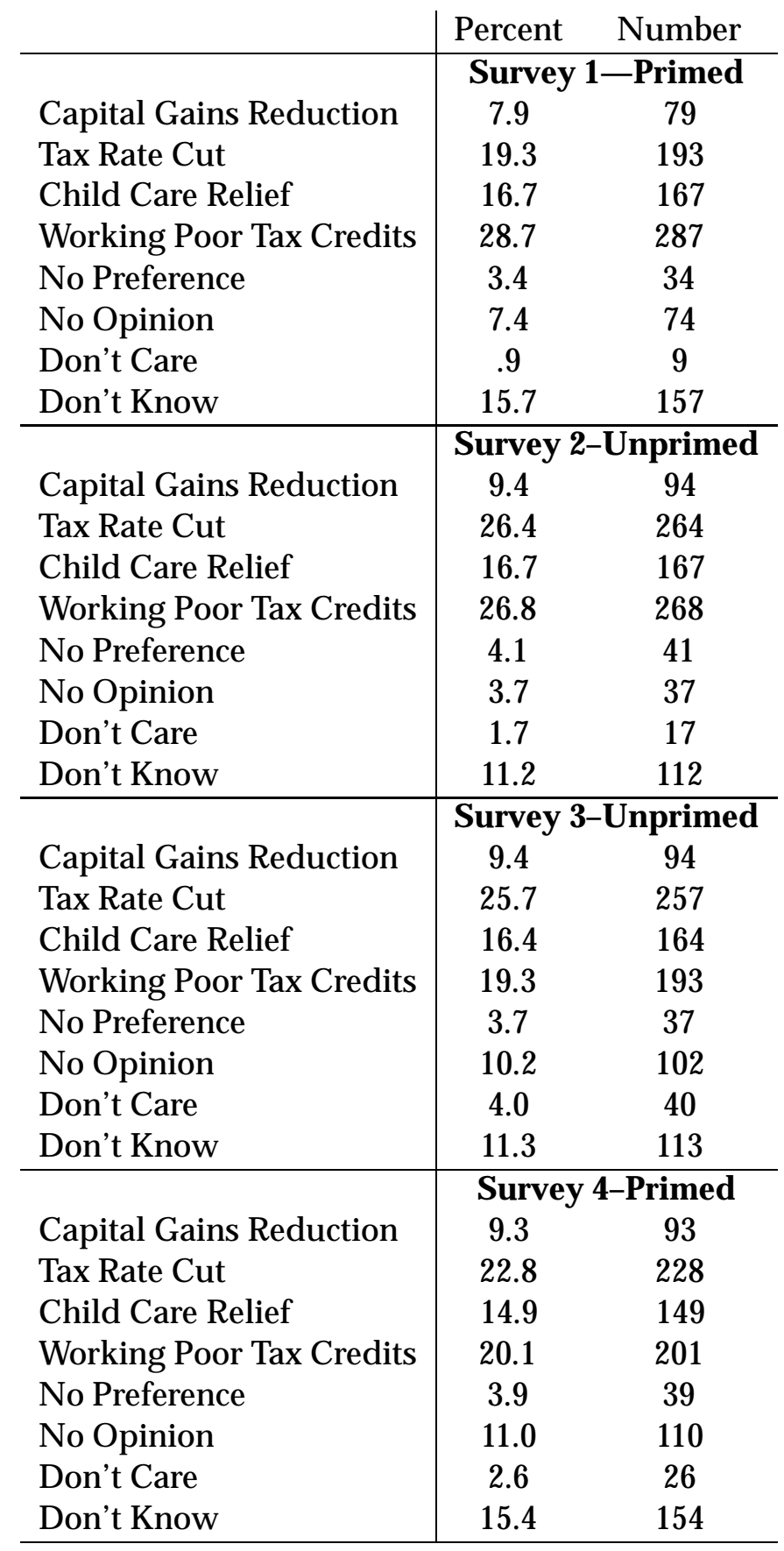


Table 9: Multinomial Logit Results on Uses of Budget Surplus

\begin{tabular}{|c|c|c|c|c|}
\hline Variables & Reduce Taxes & National Debt & Education & Social Security \\
\hline & & robability of $\mathrm{D}$ & agree to $\mathrm{A}$ & \\
\hline Constant & $-2.64^{*}$ & .32 & $-1.99^{* *}$ & $-1.10^{* *}$ \\
\hline & .58 & .53 & .57 & .55 \\
\hline Women & .07 & $.45^{* *}$ & $-.71^{* *}$ & -.22 \\
\hline & .20 & .20 & .21 & .20 \\
\hline Age & .009 & $-.07^{*}$ & $.16^{* *}$ & -.02 \\
\hline & .05 & .05 & .05 & .05 \\
\hline Children & $-.65^{* *}$ & -.10 & -.15 & $.43^{* *}$ \\
\hline & .23 & .22 & .25 & .23 \\
\hline Education & $.32^{* *}$ & $-.20^{* *}$ & -.06 & -.06 \\
\hline & .08 & .08 & .08 & .08 \\
\hline Income & .05 & -.01 & $.11^{*}$ & .06 \\
\hline & .07 & .06 & .07 & .07 \\
\hline Single & .20 & -.14 & -.18 & .21 \\
\hline & .28 & .27 & .29 & .28 \\
\hline Formerly Married & .18 & -.29 & $-.38^{*}$ & $.52^{* *}$ \\
\hline & .27 & .28 & .28 & .26 \\
\hline Black & $-.83^{* *}$ & $.82^{* *}$ & -.53 & -.34 \\
\hline & .40 & .32 & .49 & .41 \\
\hline Democrat & $.69^{* *}$ & -.28 & $-.89 * *$ & $-.80^{* *}$ \\
\hline & .22 & .23 & .28 & .25 \\
\hline Republican & $-.49^{*}$ & .03 & $.65^{* *}$ & -.12 \\
\hline & .26 & .24 & .23 & .23 \\
\hline & & bability of Dor & Know to & gree \\
\hline Constant & $1.08^{*}$ & $1.83^{*}$ & .06 & $1.67^{* *}$ \\
\hline & .42 & .44 & .48 & .43 \\
\hline Women & $.78^{* *}$ & $.72 *$ & $.22^{*}$ & $.54^{* *}$ \\
\hline & .15 & .15 & .16 & .15 \\
\hline Age & $-.05^{*}$ & -.04 & $.08^{* *}$ & $-.10^{* *}$ \\
\hline & .03 & .04 & .04 & .03 \\
\hline Children & $-.46^{* *}$ & -.16 & $-.71^{* *}$ & $-.47^{* *}$ \\
\hline & .18 & .18 & .19 & .18 \\
\hline Education & -.04 & $-.26^{* *}$ & $-.22^{* *}$ & $-.20^{* *}$ \\
\hline & .06 & .06 & .07 & .06 \\
\hline Income & $-.10^{* *}$ & -.06 & .08 & -.04 \\
\hline & .05 & .05 & .08 & .06 \\
\hline Single & .26 & .02 & .06 & -.12 \\
\hline & .21 & .2 & .24 & .21 \\
\hline Formerly Married & -.13 & $-.26^{*}$ & $-.57^{* *}$ & $-.47^{* *}$ \\
\hline & .21 & .21 & .23 & .22 \\
\hline Black & -.17 & $.45^{*}$ & .24 & $.40^{*}$ \\
\hline & .26 & .28 & .29 & .26 \\
\hline Democrat & $-.59^{* *}$ & $-.87^{* *}$ & $-1.24^{* *}$ & $-1.15^{* *}$ \\
\hline & .18 & .17 & .20 & .18 \\
\hline Republican & $-1.24^{* *}$ & $-.99 * *$ & $-.77^{* *}$ & $-.86^{* *}$ \\
\hline & .19 & .19 & .22 & .20 \\
\hline
\end{tabular}


Table 10: Multinomial Logit Model of Budget Surplus Uses

\begin{tabular}{|c|c|c|c|c|}
\hline \multirow[b]{2}{*}{ Variables } & \multicolumn{4}{|c|}{ Probability of Ranking Relative to Capital Gains Reduction } \\
\hline & Tax Rate Cut & Child Care Relief & Working Poor Credits & No Opinion \\
\hline \multirow[t]{2}{*}{ Constant } & $1.18^{* *}$ & $2.21^{* *}$ & $2.00^{* *}$ & $2.48^{* *}$ \\
\hline & .37 & .39 & .39 & .38 \\
\hline \multirow[t]{2}{*}{ Women } & $.24^{*}$ & $.65^{* *}$ & $.54^{* *}$ & $.81^{* *}$ \\
\hline & .18 & .19 & .18 & .18 \\
\hline \multirow[t]{2}{*}{ Primed } & -.08 & .09 & $.35^{* *}$ & $.42^{* *}$ \\
\hline & .16 & .18 & .17 & .17 \\
\hline \multirow[t]{2}{*}{ Interaction } & -.12 & -.08 & $-.39^{*}$ & -.27 \\
\hline & .25 & .28 & .26 & .26 \\
\hline \multirow[t]{2}{*}{ Age } & .006 & $-.16^{* *}$ & .003 & .02 \\
\hline & .03 & .03 & .03 & .03 \\
\hline \multirow[t]{2}{*}{ Children } & $.35^{* *}$ & $.55^{* *}$ & $.45^{* *}$ & .08 \\
\hline & .15 & .16 & .15 & .15 \\
\hline \multirow[t]{2}{*}{ Education } & .01 & -.04 & $-.07^{*}$ & $-.20^{* *}$ \\
\hline & .05 & .06 & .05 & .06 \\
\hline \multirow[t]{2}{*}{ Income } & $-.06^{*}$ & $-.26^{* *}$ & $-.28^{* *}$ & $-.16^{* *}$ \\
\hline & .04 & .05 & .05 & .06 \\
\hline \multirow[t]{2}{*}{ Single } & $-.37^{* *}$ & -.19 & -.19 & $.23^{*}$ \\
\hline & .17 & .18 & .18 & .18 \\
\hline \multirow[t]{2}{*}{ Formerly Married } & -.03 & .18 & .04 & .14 \\
\hline & .20 & .22 & .20 & .21 \\
\hline \multirow[t]{2}{*}{ Black } & .18 & $.82^{* *}$ & $.81^{* *}$ & $.71^{* *}$ \\
\hline & .29 & .28 & .27 & .28 \\
\hline \multirow[t]{2}{*}{ Democrat } & $-.22^{*}$ & .10 & $.28^{*}$ & $-1.09^{* *}$ \\
\hline & .16 & .17 & .16 & .17 \\
\hline \multirow[t]{2}{*}{ Republican } & -.15 & $-.85^{* *}$ & $-.88^{* *}$ & $-1.50^{* *}$ \\
\hline & .14 & .17 & .16 & .15 \\
\hline
\end{tabular}

